\title{
1 Examining trajectories of change for prosperous forest landscapes in Cambodia
}

2

3 Rebecca Anne Riggs ${ }^{a b^{*}}$, James Douglas Langston ${ }^{\text {abc }}$, Emilie Beauchamp ${ }^{\mathrm{d}}$, Henry Travers ${ }^{\mathrm{e}}$, Sereyrotha Ken ${ }^{\mathrm{f}}$,

4 Chris Margules ${ }^{\mathrm{ag}}$

5

$6 \quad{ }^{a}$ Centre for Tropical Environmental and Sustainability Science, James Cook University, Cairns, QLD 4870,

$7 \quad$ Australia; Rebecca.riggs@my.jcu.edu.au, chrismargules@gmail.com

$9 \quad$ bTanah Air Beta, Batu Karu, Tabanan, Bali 82152, Indonesia

${ }^{\mathrm{e}}$ Interdisciplinary Centre for Conservation Science, Department of Zoology, University of Oxford, Oxford, OX1

3SZ UK, henry.travers@,zoo.ox.ac.uk

19

${ }^{\mathrm{c}}$ Faculty of Forestry, Forest Sciences Centre, University of British Columbia, 2424 Main Mall, Vancouver, BC V6T 1Z4, Canada;

${ }^{\mathrm{d}}$ International Institute for Environment and Development (IIED), London, WC1X *NH, United Kingdom, emilie.beauchamp@iied.org

fWildlife Conservation Society Cambodia Program, \#21, Street 21, Sangkat Tonle Bassac, PO Box 1620, Phnom Penh, Cambodia, sken@wcs.org

gInstitute for Sustainable Earth and Resources, Faculty of Mathematics and Natural Sciences, University of Indonesia, Kota Depok, Java Barat 16424, Indonesia

*corresponding author: Rebecca Anne Riggs

Email: Rebecca.riggs@my.jcu.edu.au

ORCID: 0000-0002-0403-8669

\section{Key words}

Landscape transitions, conservation development trade-offs, transdisciplinary research, Cambodia, scenarios

\section{Acknowledgements}

We are grateful to the families that hosted us in Cambodia and the people who shared their perspectives and stories. We thank the many organizations that guided and enabled this research, with special thanks to the Wildlife Conservation Society and the Ministry of Environment. This study is part of $\mathrm{PhD}$ research on 'Socialecological Impacts of Landscape Transitions in Southeast Asia'. 
43 Tropical forest landscapes are undergoing rapid transition. Rural development aspirations are rising, and land

44 use change is contributing to deforestation, degradation, and biodiversity loss, which threaten the future of

45 tropical forests. Conservation initiatives must deal with complex social, political, and ecological decisions

46 involving trade-offs between the extent of protected areas and quality of conservation. In Cambodia,

47 smallholders and industrial economic land concessions drive deforestation and forest degradation. Rural

48 economic benefits have not kept pace with development aspirations and smallholders are gradually expanding

49 agriculture into protected forests. We examine the drivers and effects of rural forest landscape transitions in

50 Cambodia to identify trade-offs between conservation and development. Using historical trends analysis and

51 information gathered through key informant interviews, we describe how local communities perceive social and ecological changes, and examine the implications of local development aspirations for conservation. We explore three scenarios for the future of conservation in Cambodia, each with different conservation and community development outcomes. We contend that conservation efforts should focus on strengthening governance to meet social and environmental requirements for sustainable forest landscapes. We suggest potential entry points for governance improvements, including working with local decision-makers and fostering collaboration between stakeholders. There is a need for realistic priority setting in contested tropical forest landscapes. Prosperous rural economies are a necessary but not sufficient condition for conservation.

\section{Introduction}

61 Negotiate a river by following its bends, enter a country by following its customs.

62 Khmer Proverb

63

64 Tropical forest landscapes are in transition. Demand for the conservation of global public goods, including 65 irreplaceable tropical biodiversity, is competing with pressures for local social and economic development.

66 Seventy-three percent of tropical and sub-tropical deforestation is due to the conversion of forest to agriculture

67 (FAO, 2016). Throughout the tropics, human population and development aspirations continue to grow.

68 Countries are pursuing greater affluence through infrastructure development (Laurance \& Arrea, 2017). Rural

69 economies are still highly dependent on agricultural commodities but there is increasing investment in manufacturing and services to stimulate economic growth (Szirmai, 2012). Global efforts to conserve tropical 

degradation (Balmford \& Cowling, 2006; Ghazoul \& Chazdon, 2017).

Cambodia lies within the Indo-Burma biodiversity hotspot (Mittermeier, 2004) and is one of the least developed countries in Southeast Asia. In contrast to neighbouring countries Thailand and Vietnam, Cambodia has not yet passed through a forest transition; the shift from net deforestation to net reforestation (Leblond, 2019; Mather, 1992; Meyfroidt \& Lambin, 2008b; Riggs et al., 2018). The Government of Cambodia allocates $41 \%$ of the national territory to protection. But these protected areas (PAs) are vulnerable to pressures associated with lack of political and public support, food insecurity, poverty, and low levels of education (Johnson et al., 2014; Mahanty \& Milne, 2015). These issues are characteristic of many of the countries within Southeast Asia that struggle to reconcile economic interests with forest protection (Estoque et al., 2019). Yet divergent trends exist; forest cover across the region is entwined with contextual factors and processes that occur at sub-national scales. Frontier forest areas exhibit high rates of deforestation and illegal activity, while other areas traditionally used for agriculture are now a major source of timber production (Curran et al., 2004; Meyfroidt \& Lambin, 2008a). The sustainability trajectories of these landscapes often depend on governance - the ways decisions are made and implemented (Adger et al., 2003; Graham et al., 2003). Governance determines the allocation of and access to resources, the availability of goods and services, and the incentives and policies for inclusive sustainable development.

In Cambodia, forest landscapes are on a trajectory towards an unsustainable future. Governance is not ensuring equitable development opportunities from resource conversion (Beauchamp et al., 2018b; Hansen et al., 2013; Riggs et al., 2018). Cambodia's economic transformation following the Khmer Rouge conflict resonates with wider trajectories of change across Southeast Asia (Hughes \& Un, 2011). However, rapid economic growth does not capture the full spectrum of political and social dynamics that have shaped Cambodia's forest governance. The manipulation of forest policy reform by political elites and the early failures of externally driven forest management regimes have led to a culture of personal enrichment and patron-client relations (Cock, 2016; Le Billon, 2000; Mahanty \& Milne, 2015). In recent history, protected forests have been a source of development benefits for rural forest-dependent Cambodians (Clements et al., 2014b). But agrarian change via the expansion 
101 rapid pace (Davis et al., 2015; Kong et al., 2019). Increasing access to infrastructure, education, and physical

102 assets is enabling more lucrative livelihood strategies (Jiao et al., 2017). Rent seekers act to gain wealth without

103 reciprocal gains to society, contributing to inequality and political imbalance (Milne, 2015; Tullock, 1967). As

104 development needs and aspirations rise, the economic foundations for development will likely require

105 relinquishing much of the PAs to other, more profitable land-uses with more inclusive benefits. Efforts to

106 conserve significant Cambodian biodiversity must reconcile these basic trade-offs.

107

108 Navigating conservation and development trade-offs and synergies between humans and natural resources has

109 become one of the defining issues of the Anthropocene (Lewis et al., 2015; Mehrabi et al., 2018; Palomo et al.,

110 2014). Fervent debates over intensified 'land sparing' farming approaches vs. low intensity 'land sharing'

111 systems highlight the dichotomy between biodiversity conservation and human development needs (Kremen,

112 2015; Phalan et al., 2011). Recently, these debates are converging to a discourse beyond that dichotomy,

113 towards multi-functionality (Fischer et al., 2017). The path to sustainability in tropical forest landscapes is

114 complex and requires comprehensive considerations of multiple knowledge systems, actors, and decision

115 makers (Cornell et al., 2013; Gibson et al., 2000; van Noordwijk, 2017). Too often, efforts to conserve forested

116 landscapes do not take into account the needs and aspirations of people living in those landscapes (Agrawal \&

117 Gibson, 2001; Boedhihartono et al., 2018; Brown, 2002). Without local support, conservation is not sustainable.

118 Yet finding locally appropriate development pathways that might simultaneously have a more benign effect on

119 biodiversity is challenging (Terborgh \& Peres, 2017).

121 In this paper, we present a case study of two forest landscapes representing the conservation development nexus

122 in Cambodia. We address the following questions: What are the historic and future trajectories of change in

123 forest landscapes in Cambodia? What strategies might nurture landscape transitions for better social and

124 environmental management decisions at the landscape scale? Within this context, we examine socio-economic,

125 political, and environmental components of landscape change to identify trade-offs between biodiversity

126 protection and local community development. We take an inductive, grounded theory approach using place-

127 based transdisciplinary practices to analyze the contexts of change (Brandt et al., 2013; Corbin \& Strauss, 1990;

128 Thomas, 2006). From this, we derive three potential scenarios with contrasting strategies and different outcomes

129 for conservation and development. In both landscapes, efforts to conserve tropical forests compete with local

130 development aspirations and exogenous economic and political forces. Conservation agencies, including non- 
131 government and government organizations, attempt to reconcile conservation and development trade-offs, but

132 must deal with rapidly changing and uncertain circumstances. We use key informant interviews, focus group

133 discussions, and quantitative household surveys to examine underlying drivers and effects of rural forest

134 landscape transitions in Cambodia, emphasising how changes are perceived by local communities and their

135 impact on the natural environment. Our research is guided by the ethos of 'embedded science', wherein we

136 acknowledge the complexity and depth of social-ecological challenges in landscapes, and apply

137 transdisciplinary research principles, working with local partners to generate research objectives, and integrating

138 knowledge from multiple disciplines to solve real world problems (Lang et al., 2012; Langston et al., 2019;

139 Scholz, 2000).

141 Understanding and nurturing conservation and development in Cambodia's changing landscapes

143 At the base of the Lower Mekong, The Kingdom of Cambodia is emerging as a rapidly developing state.

144 Described as a frontier of change (Mahanty \& Milne, 2015), political dynamics and market processes are

145 shaping economic growth and natural resource exploitation. Development banks and foreign investment are

146 promoting regional economic integration within the Greater Mekong Sub-region, with widespread investment in

147 transport networks and infrastructure (ADB, 2012, 2016). Industrial agriculture, new road development and

148 demand for land among the rural population are driving landscape transitions; the social, economic, and

149 environmental changes apparent at a landscape-scale (Bürgi et al., 2005; Ichikawa et al., 2006; Zhang et al., 150 2016).

152 Emerging from landscape ecology, landscape transitions recognise that human influences, including economics,

153 politics, social structures, technology and value systems, shape the natural environment and the use of natural

154 resources, and vice versa (Bailes, 1985; Kaplan \& White, 2002; Russell, 1998). Studies examining landscape

155 transitions draw from a social-ecological systems (SES) perspective, which explicitly acknowledges feedback

156 links between human (communities, society, economy) and natural systems (Berkes et al., 2008; Berkes \&

157 Folke, 1998). A SES systems perspective recognizes that understanding what is driving change in landscapes,

158 and how these changes unfold, requires a multi-level systems approach; examining both internal and external

159 processes that shape outcomes at different scales (Turnheim et al., 2015). Applying an SES perspective can lead

160 to critical insights into the governance arrangements that influence the pace and direction of environmental 
161 change, and opportunities to enhance sustainable development pathways (Dewi et al., 2017; Ostrom, 2009;

162 Pokorny \& De Jong, 2015).

163

164 In the context of Cambodia, landscape transitions provide a useful framework for analysing the temporal

165 interactions between socio-economic, political, cultural, and environmental complexities in rural forest

166 landscapes. In this study, we examine landscape change guided by a SES perspective, focusing on landscape as

167 a form of 'place', drivers of change, and leverage points for nurturing change. By considering landscapes within

168 the concept of place, we acknowledge the political, cultural, economic, and environmental interactions that

169 occur within a space, and how these interactions shape identity, worldviews and actions (Altman \& Low, 2012;

170 Cheng et al., 2003; Williams \& Stewart, 1998). Place is not a static concept; it is continually influenced by

171 social, political, and biophysical dynamics (Greider \& Garkovich, 1994). These interactions can be captured by

172 analyzing drivers of change, including non-linear relationships between political and market forces, local

173 behaviour and decision-making, and subsequent environmental impacts (Lambin \& Meyfroidt, 2010; Meyfroidt

174 et al., 2018; Warrener, 2004; Wood \& Handley, 2001). With an in-depth understanding of change processes

175 within a landscape, we can draw insights into future aspirations and potential landscape trajectories from a

176 diverse range of sources. Opportunities to influence or 'nudge' change may appear through the identification of

177 leverage points - places to intervene in a system (Meadows, 1999; Thaler \& Sunstein, 2009).

179 Leveraging landscape transitions to improve social and environmental outcomes requires explicit identification

180 of trade-offs (Brown, 2004; Hirsch et al., 2011; McShane et al., 2011). In Cambodia, both conservation and

181 development are stated as priorities in the Government's long-term strategic development plans, yet in reality

182 there are few opportunities for synergies (Beauchamp et al., 2018b). The Government established Economic

183 Land Concessions (ELCs) in 2005 after the demise of the timber concessions in the late 1990s to drive rural

184 development through large scale industrial agriculture. Implementation of ELCs has led to more than 2 million

185 hectares of Cambodia's land being leased to private companies for economic development and this has greatly

186 increased deforestation (Davis et al., 2015). The rapid spread of concessions and scramble for land resulted in

187 social unrest in the form of land disputes, forced evictions and land grabs throughout Cambodia (Neef et al.,

188 2013). Social Land Concessions (SLCs) to provide land to poor and landless Cambodians also require land in

189 forest areas, contributing to further conflict and deforestation (LICADHO, 2015; Rainey et al., 2010). Since

190 2012, Prime Minister Hun Sen has maintained a moratorium on the allocation of new ELCs. Protected areas, 
191 already vulnerable to politically profitable cancellation, or encroachment, are currently influenced by a complex

192 network of smallholders, industrial agriculture, SLCs, and a growing presence of energy and transport

193 infrastructure.

195 Protected area management in Cambodia is supported by international and local non-government organizations,

196 drawing on scientific methods for conservation planning and management (Clements et al., 2014b; Gray \&

197 Phan, 2011; Ibbett et al., 2017). Yet as Cambodia's rural landscapes become increasingly shared by diverse

198 actors, finding sustainable landscape trajectories that meet the needs of stakeholders, including government

199 agencies, private bodies, local communities and conservation advocates, is inherently challenging. Recent

200 decentralization placed protected area management under the purview of the Provincial Department of

201 Environment (PDOE). Decisions are overseen by the General Directorate of Administration for Nature

202 Conservation and Protection (GDANCP) and must be approved by the Provincial Governor. Conflicting

203 conservation and development initiatives are often negotiated among a range of stakeholders, but negotiation is

204 constrained by politics (Paley, 2015). Patronage networks exert substantial influence over the development of

205 forest land, with little room for community involvement in decision making (Persson \& Prowse, 2017).

206 Conservation agencies must navigate provincial and national directives whilst responding to the needs of local

207 people living in and around PAs. In general, the success of conservation depends on public support and societal

208 values that shape conservation policy (Brown et al., 2010; Miller \& Hobbs, 2002; Rose, 2015). The risk is that

209 conservation in Cambodia will not likely succeed if it does not contribute to socially inclusive development and

210 build a constituency for sustainable natural resource management. Yet navigating social-economic and political

211 components of an unpredictable and complex environment requires accepting some irreversible costs. This

212 paper provides contextual information to stimulate a practical evaluation of the trade-offs of different

213 conservation and development decisions at multiple levels in Cambodia.

214

215 Study sites: The Keo Seima Wildlife Sanctuary and Northern Plains Landscape

216 We selected two study sites which exemplify conservation and development pressures on Cambodia's protected

217 area network (Figure I). Both landscapes are subject to long-term interventions from conservation agencies,

218 which have influenced management decisions and contributed to a repository of diachronic data on social and

219 biophysical components of the landscape. The Keo Seima Wildlife Sanctuary (KSWS) and surrounding area has

220 undergone transformative agrarian change since conservation activities began in early 2000s, most apparent 
221 since the construction of the major road linking the province to Phnom Penh that began in 2007 (Clements et al.,

222 2014a). In contrast, the Northern Plains has remained relatively isolated from neighbouring provinces and is

223 transitioning at a slower pace than KSWS in the Eastern Plains of Cambodia. The two landscapes are situated in

224 the provinces with the highest population growth, with annual growth rates of 3.5\% in Preah Vihear and 3.4\% in

225 Mondulkiri (NIIS, 2019). Similar natural resource governance arrangements exist in both landscapes, with a

226 significant exception being the strong presence of indigenous communities in the Eastern Plains. Prior to 2016,

227 PAs in Cambodia were under the management of the Ministry of Environment (MoE) or the Ministry of

228 Agriculture, Forestry, Fisheries (MAFF) (Souter et al., 2016). In 2016, sub-degree 69 transferred PAs under the

229 authority of the MAFF to the MoE. In the two study sites government-led PA management is supported by the

230 Wildlife Conservation Society (WCS) Cambodia Program, which has been actively engaged in both landscapes

231 since 2000.

232

$233 \mathrm{KSWS}^{1}(292,690 \mathrm{ha})$ is located within Mondulkiri Province. The local population consists of indigenous ethnic

234 groups, primarily Bunong or Stieng, and ethnic Khmer. Rural livelihoods are predominantly derived from

235 agriculture and forest use, including rain-fed rice paddy, cassava, cashew, rubber and resin tapping from

236 Dipterocarpus species, D. alatus and D. intricatu (Travers et al., 2015). KSWS conserves large areas of both

237 Annamitic evergreen forest and deciduous dipterocarp forests of the eastern plains, forming a complex mosaic

238 of forest types that provided habitat for endangered flora and fauna. The wildlife sanctuary includes an

239 established REDD+ project, eco-tourism, Indigenous Communal Tenure (ICT) and community forestry schemes

240 (Travers et al., 2016).

241

242 Large scale development projects exist and are planned in the landscape, including mining, economic land

243 concessions for rubber, new roads, and power transmission lines. Due to the proximity of the Vietnamese

244 border, illegal logging of high value timber is a major concern for PA authorities. Migration and demand for

245 farming land continues to drive conversion of forest to agriculture in areas in close proximity to roads and

246 markets. While deforestation is reducing wildlife habitat, conservation agencies perceive hunting to be the major

247 imminent threat to terrestrial species. Biodiversity monitoring shows that populations of ungulates are

248 decreasing but that primate populations are stable (unpublished data). Reduction or local extinction of

\footnotetext{
${ }^{1}$ Formerly Seima Protection Forest, management transferred from MAFF to MOE in 2016
} 
249 populations of such species changes floristic and faunistic composition of forests (Wright, 2003). If species

250 populations are reduced to such low levels that they are "ecologically extinct", they may be unable to fulfil their

251 ecological role, with repercussions on the long-term diversity and health of tropical forests (Redford, 1992).

253 The Northern Plains Landscape consists of a network of three PAs in Preah Vihear Province, the Kulen Promtep

254 Wildlife Sanctuary (KPWS), Preah Roka Wildlife Sanctuary (PRWS) and Chhep Wildlife Sanctuary (CWS)2,

255 collectively encompassing 535,000 hectares. Rural communities primarily practice rain-fed paddy cultivation;

256 some households also grow cash crops including cassava and cashew. Additional income is made through resin-

257 tapping and the collection of Non Timber Forest Products (NTFPs) (Beauchamp et al., 2018a). Villages inside

258 the PAs contain a mixture of indigenous and non-indigenous people, former soldiers, and recent immigrants

259 from the central plains of Cambodia (Clements, 2012). Most of the Northern Plains landscape is dry deciduous

260 forest, although patches of evergreen forest and other forest types exist. Forests and agricultural areas are habitat

261 for critically endangered and vulnerable mammal and bird species.

262

263 Since 2008, over 61,000 ha of land inside CWS and KPWS has been allocated to economic and social land

264 concessions, increasing the population of the area and impetus for illegal activities. Deforestation is prominent

265 in these areas. Conversion of forest to agriculture by local communities and immigrants also occurs, but a

266 number of interventions are working to strengthen local incentives for conservation, including wildlife friendly

267 agriculture, payments for environmental services (PES) programs, ecotourism and land use planning (Clements

268 et al., 2014b). The longest of these programs involves small conditional payments to local people to protect the

269 nests of highly threatened bird species from collection for consumption and trade. The program, established in

2702003 and currently implemented across 24 villages, has contributed to long term partnerships between local

271 villagers and protected area managers (Beauchamp et al., 2018a; Clements et al., 2013). Monitoring of bird

272 nests and fledglings in CWS and KPWS show that conservation interventions may be effective in maintaining

273 bird populations, but no mechanisms exists for combating habitat loss by conversion in concessions (Harrison \&

274 Mao, 2017). According to Harrison and Mao (2017), the number of bird nests and fledglings rose between 2002

275 and 2008, after which they stabilised and then have fallen at a steady rate since 2012. The decrease in the

\footnotetext{
${ }^{2}$ Formerly Preah Vihear Protection Forest, management transferred from MAFF to MOE in 2016
} 
number of nests and fledglings is attributed to habitat loss, logging of high value timber in nesting sites, hunting, and egg collection.

Fig. I Location of study sites, villages surveyed, and deforestation between 2000 and 2017. Land cover data including forest cover, administrative data and other spatial components of the landscapes was obtained from WCS's private spatial dataset. Detailed methodology is available in Rainey et al. (2010) and Evans et al. (2009)

\section{Methods}

284 We have visited the landscapes of focus for short periods annually since 2015 to explore and discuss research objectives with natural resource management agencies. Following principles of inductive research (Thomas, 2006), inquiry was driven by a broad set of issues and not a predetermined hypothesis. We reviewed existing data available for both landscapes, including forest cover change, biodiversity surveys and household surveys. Our preliminary findings indicated a wealth of available quantitative data covering both biophysical and social attributes of the study sites. We found gaps in information on how local communities perceive the social and environmental components of their landscapes and the governance arrangements that influence outcomes at a landscape level. These gaps emerged due to the changing nature of landscapes; past partnerships appeared to be

292 based on informal relationships, which inherently change over time. Relationships and institutional memory have not kept pace with new leadership, new actors, and changing societal values.

We spent six weeks in each landscape between November 2017 - February 2018, engaging with natural resource management agencies and local communities. Drawing from conceptual and empirical understandings of social-ecological interactions of landscape change (Cheng et al., 2003; Meyfroidt et al., 2018), principal attention was given to the following characteristics:

- Local perceptions of landscape transitions and future aspirations

- Institutional arrangements influencing conservation and development outcomes

- Leverage points for development pathways Northern Plains we visited Dangphlat, Kunapheap and Antil. Key informant interviews and focus group discussions were conducted by two authors and a translator. Translation of key concepts occurred prior to 
meetings. During the interviews and discussions, conversation was translated continuously, as well as after each

307 meeting for further clarification. We sought to build from existing datasets through information gathered in

308 formal interviews and focus groups and informal discussions for a more holistic problem focused approach

309 (Leavy, 2016). We selected the villages to represent low, medium, and high accessibility inside or on the border

310 of an established PA. As transport infrastructure is often an indicator of rural development (Roberts et al.,

311 2006), accessibility was selected to capture villages at different stages of landscape transitions. Time and

312 financial constraints limited our coverage to three villages in each landscape. Our second criterion was the

313 presence of contemporary issues in rural Cambodia within the village, including economic land concessions,

314 transport infrastructure, indigenous communal tenure, migration and various conservation schemes (Table I).

316 Table I Overview of villages selected for study, including socio-economic conditions, conservation activities,

317 and sample contribution to study. Basic Necessities Survey (BNS) scores (Davies \& Smith, 1998) are used as an

318 indicator of wealth and normalised according to the maximum possible score for each landscape. Score is for

319 comparison between villages but does not represent standardized value for comparison between the Northern

$320 \quad$ Plains and Eastern Plains

\begin{tabular}{|c|c|c|c|c|c|c|}
\hline \multirow[b]{2}{*}{ Village } & \multicolumn{3}{|c|}{ Northern Plains } & \multicolumn{3}{|c|}{ KSWS } \\
\hline & Dangphlat & Kunapheap & Antil & Sre Preah & Gati & $\begin{array}{l}\text { Chak } \\
\text { Char }\end{array}$ \\
\hline Village Accessibility & High & Medium & Low & High & Medium & Low \\
\hline Dominant livelihoods & $\begin{array}{l}\text { Paddy } \\
\text { rice, cash } \\
\text { crops, } \\
\text { labour }\end{array}$ & $\begin{array}{l}\text { Paddy rice, } \\
\text { chamkar } \\
\text { rice, cash } \\
\text { crops }\end{array}$ & $\begin{array}{l}\text { Paddy rice, } \\
\text { labour, cash } \\
\text { crops }\end{array}$ & $\begin{array}{c}\text { Cash } \\
\text { crops, } \\
\text { labour, } \\
\text { paddy rice }\end{array}$ & $\begin{array}{l}\text { Chamkar } \\
\text { rice, } \\
\text { labour, } \\
\text { cash } \\
\text { crops }\end{array}$ & $\begin{array}{l}\text { Paddy } \\
\text { rice, cash } \\
\text { crops, } \\
\text { labour }\end{array}$ \\
\hline Ethnicity & $\begin{array}{l}\text { Khmer, } \\
\text { Kuoy }\end{array}$ & Khmer & Khmer & $\begin{array}{l}\text { Banong, } \\
\text { Khmer }\end{array}$ & $\begin{array}{l}\text { Banong, } \\
\text { Khmer }\end{array}$ & $\begin{array}{l}\text { Banong, } \\
\text { Khmer }\end{array}$ \\
\hline $\begin{array}{c}\text { Basic Necessities Score } \\
\text { (mean and standard } \\
\text { deviation) }\end{array}$ & $0.68,0.11$ & $0.59,0.11$ & $0.55,0.11$ & $0.63,0.11$ & $0.63,0.12$ & $0.57,0.11$ \\
\hline $\begin{array}{l}\text { Indigenous Communal } \\
\text { Tenure }\end{array}$ & No & No & No & No & Yes & Yes \\
\hline \multicolumn{7}{|l|}{ Conservation presence: } \\
\hline Protected Area & $\checkmark$ & & $\checkmark$ & $\checkmark$ & $\checkmark$ & $\checkmark$ \\
\hline Birds Nest Protection & $\checkmark$ & & $\checkmark$ & & & \\
\hline Wildlife friendly rice & $\checkmark$ & & & & & \\
\hline Community Forest & & $\checkmark$ & & & & \\
\hline REDD+ & & & & $\checkmark$ & $\checkmark$ & $\checkmark$ \\
\hline
\end{tabular}




\begin{tabular}{|ccccccc|}
\hline $\begin{array}{c}\text { Economic Land } \\
\text { Concession }\end{array}$ & Nearby & Nearby & Nearby & Nearby & Distant & Nearby \\
$\begin{array}{c}\text { Focus Group } \\
\text { Discussion participants } \\
\quad \text { F=Female) }\end{array}$ & $6(2 \mathrm{~F})$ & $7(2 \mathrm{~F})$ & $5(1 \mathrm{~F})$ & $7(3 \mathrm{~F})$ & $7(2 \mathrm{~F})$ & $7(2 \mathrm{~F})$ \\
$\quad \begin{array}{c}\text { Key Informant } \\
\text { Interviews }\end{array}$ & 13 & 11 & 10 & 10 & 10 & 12 \\
$\begin{array}{c}\text { Households surveyed } \\
\text { 2017/2018 }\end{array}$ & 111 & 44 & 58 & 32 & 31 & 31 \\
\hline
\end{tabular}

322 Key Informant Interviews

323 We selected our key informants based on their involvement in a specific component of the landscape, such as

324 agriculture, small business, health, education, conservation, migration, decision-making, and wealth. Selection

325 began with a consultation with the village chief, followed by snowball sampling whereby we asked individuals

326 (key informants or villagers) to recommend interviewees until we reached a saturation point (Newing, 2010).

327 Recognizing the heterogeneous nature of social landscapes, informants represented a range of age groups,

328 income levels and cultural backgrounds. We interviewed 65 informants at the village level (Table 1) and

329 conducted a further 47 interviews with representatives of government and non-government organizations

330 engaged in natural resource management decisions in the landscapes. Organizations operated at various scales,

331 from village to national, but actions directly impacted the landscapes of focus. Grounded theory (Corbin \&

332 Strauss, 1990) - the integration of data collection and analysis - guided our interview process. Key informant

333 interview questions were structured around themes of governance, natural resources, wealth, development

334 aspirations and perceptions of change over time, but tailored to individuals and topics. We analysed each

335 interview for the emergence of issues and concepts relevant to our research objectives, and pursued these issues

336 further in subsequent interviews. We followed principles of appreciative inquiry (Reed, 2006), discussing

337 potential solutions to issues as they emerged locally.

\section{Focus Group Discussions}

340 In each village, we convened a focus group to discuss drivers of change and social-ecological impacts. We

341 worked with the village chief to invite participants in person, selecting villagers in the older demographic with

342 knowledge of the history of the village. We ensured the final group reflected the diversity of household incomes

343 in the village and included both women and men to build consensus on the discussion outputs. In each group,

344 we used historical trends analysis (adapted from Basuki et al., 2011; Boedhihartono, 2012; Shepherd \&

345 Blockhus, 2008) to understand social-ecological change and local perspectives at the village scale. By 
constructing histories through the identification of events, we hoped to gain insights on integrated causes and

347 effects of specific change processes, capturing trends over time (Walters, 2017). In each discussion, we built a

348 historical timeline for the landscape, including social, environmental and political events that occurred within

349 the village and at higher scales. We did not define a timeframe, allowing participants to offer information on

350 what they felt was relevant to the discussion. We asked participants to identify key events that had an impact on

351 natural resources, and whether the impact was positive or negative. We repeated the question for life in the

352 village, asking which events have brought positive and negative changes to people's lives. We did not restrict or

353 define quality of life, instead leaving the question open-ended for participants to define individually. We then

354 asked participants their future expectations for the landscape and which organizations they expected to have

355 influence in future conservation and development outcomes.

Household surveys

358 During the period of research, WCS conducted household surveys in the Northern plains landscape and in

359 KSWS. The 2017 surveys covered socio-economic information and local perceptions, and contributed to long

360 term datasets on local livelihoods in areas where conservation activities are taking place. The household survey

361 in KSWS is part of the Social Impact Assessment (SIA) for the REDD+ project. Households were randomly

362 selected in each of the twenty villages involved in the REDD+ project, with a minimum sample of thirty

363 households per village for a total of 620 responses. In villages that are separated into discrete settlements, the

364 sample was proportionally stratified by settlement. The design and purpose of the household survey in the

365 Northern Plains is to evaluate the impact of biodiversity conservation on local communities (Clements, 2012).

366 Household selection was initially random stratified sampling based on a participatory wealth ranking exercise in

367 villages inside and outside the PA network, according to the original survey design by Clements and Milner-

368 Gulland (2015). The 2017 survey followed the original survey design and involved 1046 responses from 18

369 villages, (11 within the PAs). The methodology and medium term results of the impact evaluation are described

370 in Beauchamp et al. (2018a).

372 In both sites, interviews were conducted with the household head using structured questionnaires. The Basic

373 Necessities Survey (BNS) is used in the Northern Plains and KSWS as a wealth index, specifically derived in

374 the local context. Davies and Smith (1998) outline the procedures for establishing and using the BNS to monitor

375 livelihoods in a specific location. As such, BNS scores cannot be compared across the two landscapes. For the 
purpose of this study, household surveys covering the period 2008-2014 are used to verify long term landscape trends described in interviews and focus groups. The 2017 surveys provide landscape-wide perspectives on natural resources, governance and livelihood performance.

Analysis

381 The iterative nature of grounded theory allowed for the categorization of themes as they emerged, which further

382 directed inquiry. Focus group discussions elucidated key drivers of development and consequent deforestation and degradation, which were further explored in key informant interviews. Interview content was categorized into ten themes that inductively emerged from discussions: institutions, natural resources, aspirations, migration, infrastructure, agribusiness, health, education, wealth, and illegal activities. The historical trends analysis conducted in each focus group discussion was collated for each landscape to expose key events and trends. Our analysis focused on the intersection between biophysical conditions, institutional and socio-economic processes, and knowledge, values and belief, in line with understandings of place (Cheng et al., 2003). Historical similarities between all villages gave rise to key trends, reflecting thematically similar but temporally different development pathways. Timelines allowed for exploration of themes over time, verified by historical data, observations, and secondary sources, including articles from peer-reviewed journals and grey literature. From the information gathered we identified feasible development pathways in each landscape and potential repercussions for conservation. We determine likely future scenarios and potential leverage points for navigating trade-offs. Scenarios were developed post-hoc with the intention of contrasting social-ecological change in landscapes under different conservation approaches, building from historical trends. Three scenarios were chosen to capture different conservation paradigms of exclusion, integration and prioritization. Themes highlighted in scenarios reflect those that were raised during discussions about the future of each landscape.

\section{Results}

\section{Forest landscape transition histories}

402 The pace and direction of change in rural forest landscapes in Cambodia over the past 40 years have been

403 influenced by diverse factors at multiple scales. The focus groups generated historical timelines in each village

404 documenting important social, economic, cultural, political, and environmental events. While each village 
406 Rouge (1975-1979) affected all villages, forcing communities to relocate to the district centre. Resettlement

407 occurred at various stages after 1980. When communities returned, they began a process of rebuilding

408 livelihoods, restoring farmlands and exploiting forest products for food, shelter, and income. Gradual stability

409 and tenure security between 1980 and early 2000s enabled a slow accumulation of capital and resources. Table

410 II highlights key features of the historical timeline. Focus groups, key informant interviews, and secondary

411 sources are used to expand the timeline below.

412

413 Table II Historical Timeline for the Northern Plains (left) and KSWS (right) in Cambodia. Information on

414 events were gathered in discussions in three villages in each landscape and amalgamated to form a rich history

415 of changing forest landscapes in rural Cambodia

\begin{tabular}{|c|c|c|}
\hline & Northern Plains & KSWS \\
\hline 1975 & \multicolumn{2}{|c|}{$\begin{array}{c}\text { Khmer Rouge Regime } \\
\text { People were moved from their villages to the district }\end{array}$} \\
\hline 1980 & \multirow[t]{2}{*}{$\begin{array}{c}\text { Rebuilding and Instability } \\
\text { People returned to their villages, began to } \\
\text { farm collectively and then privately. } \\
\text { Khmer Rouge maintained a presence in Preah } \\
\text { Vihear, conflict continued, and some people } \\
\text { were unable to settle in their village } \\
\text { Fear of Khmer Rouge meant people did not } \\
\text { participate in elections }\end{array}$} & $\begin{array}{c}\text { Rebuilding } \\
\text { People returned to their villages, collected } \\
\text { resin, farmed rice and vegetables, raised } \\
\text { livestock and hunted } \\
\text { Bridge and road were damaged from war, } \\
\text { repaired in } 1990 . \\
\text { Accessible villages began to grow cashew } \\
\text { Health Centre built }\end{array}$ \\
\hline \multirow[t]{2}{*}{$\begin{array}{l}1995 \\
2000\end{array}$} & & \multirow{2}{*}{$\begin{array}{c}\text { Asset transformation } \\
\text { Samling logging company established } \\
\text { Khmer migration to more accessible villages } \\
\text { Villagers buy motorbikes, open shops } \\
\text { Villagers log high value timber, grow cassava } \\
\text { and cashew } \\
\text { NGOs commence conservation and } \\
\text { development initiatives in villages }\end{array}$} \\
\hline & $\begin{array}{l}\text { Asset transformation } \\
\text { Conflict ended in 1998, and people began to } \\
\text { build houses and open shops. Bucket wells } \\
\text { were built, followed by pump wells. } \\
\text { Some people bought motorbikes. } \\
\text { More accessible village bought minitractors }\end{array}$ & \\
\hline
\end{tabular}


Capital accumulation

2007

Present
Better roads increased access to healthcare and markets

Less accessible villages bought mini-tractors

Villagers began to diversify crops, including cassava and sesame

Economic Land Concessions established and begin to clear forest

Health and education infrastructure improved
Capital accumulation and re-investment

More accessible villagers grow rubber Micro-finance available

Indigenous Communal Tenure initiatives and private land tenure established

Economic land concessions established and clear forest

Corruption and illegal logging are high concerns

Transport and communication infrastructure improve accessibility of remote villages

417 During the focus groups in the Northern Plains villages of Dangphlat, Kunapheap and Antil, participants shared

418 how guerrilla warfare between the Khmer Rouge and Government continued to threaten local communities after

419 resettlement, inhibiting their ability to recover from the war and regain social and economic stability. Villages

420 grew rice for subsistent consumption, unable to produce and sell surplus due to the continued conflict,

421 challenging environmental conditions, and Preah Vihear's relative isolation from external markets. In the 1980s,

422 households increased their income by expanding their farms, shifting from communal rice to farming as

423 households, and selling resin. When the Khmer Rouge dissolved, ex-Khmer Rouge, demobilized soldiers and

424 displaced people remained in the area, and villages consisted of large settlements comprising heterogeneous

425 groups (Clements, 2012). As conflict de-escalated in the late 1990s, households began to build their assets with

426 small shops, motorbikes, and improved houses. Gradual stability brought new infrastructure to the villages,

427 including wells, schools and basic health facilities. In the early $2000 \mathrm{~s}$, farmers in the more accessible villages

428 began to purchase mini-tractors and expand land for cultivation, contributing to growing incomes and accumulation of assets.

431 In the late 2000 s, new roads began to increase accessibility. The road from the district town to Dangphlat village

432 was initially built in 2008 and improved in 2013, creating access to healthcare, markets, and services. The road

433 to Kunapheap village was built in 2012 by the Government prior to commune elections but a local leader told us

434 the road has remained in poor condition as the Government did not allocate funding for maintenance. A good

435 road to Antil village is yet to be built, although mini-tractors and motorbikes can access the village most of the

436 year. The value of roads for improving livelihoods was highlighted in all three focus groups and in key

437 informant interviews, as stated by a young teacher in Antil village:

438 
442 With improved access to markets and mini-tractors to expand land holdings, villages in the Northern Plains have

443 recently started to produce cash crops such as cassava, cashew, and sesame. Household surveys show cash crop

444 farmers in the Northern Plains were twice as numerous in 2014 as they were in 2008, and five times as

445 numerous in 2017. Wealthier households in more accessible villages capitalize on new opportunities and

446 diversify their income, while households with smaller landholdings or in more remote villages continue to grow

447 subsistence rice. Key informants stated that when households owned a mini-tractor, they could clear more

448 forest, increase efficiency and diversify income. According to Beauchamp et al. (2018a), wealthy households in

449 the Northern Plains are more likely to own a shop and provide a service, to own a mini-tractor and a higher

450 number of cattle, and to be highly involved in programs organized by local conservation NGOs. Households

451 unable to acquire enough land, livestock, or agricultural resources to reinvest in assets or mechanised

452 agricultural practices remained in a poverty trap (Beauchamp et al., 2018a).

453

454 More recently, local leaders stated that economic land concessions have posed threats to villages, including the expropriation of land and logging of resin trees with little or no compensation. In response, households are clearing forest to secure farmland, unperturbed by its legal status as a protected area. In two of the villages, key informants reported conflict with neighbouring economic land concessions, involving loss of resin trees, issues of compensation and disagreement over land ownership. These experiences reflect reports of land-grabs throughout the region (Beban et al., 2017; Leblond, 2019). Social land concessions providing land for soldiers and their families also influence the trajectory of change in the Northern Plains. The proximity of the landscape to the Thai border has led to strategic placement of military in the area, resulting in forest clearance, other illegal activities, and a complicated social and political situation.

464 In KSWS, focus groups stressed the significance of the proximity of the villages to Vietnam as a driver of 465 economic growth for the area. In 1988, local authorities began repairing the road on both sides of the

466 Vietnamese border, allowing for trade. Subsequently, villages close to the border generated income from a range 467 of activities, including retail shops and the sale of resin, vegetables, cashew, livestock and rice. Remote villagers did not develop at the same pace; the focus group in Chak Char said the village did not start growing cashews 

concession was granted in 1994. It was logged for three dry seasons between 1997 and 1999 before closing due to the nation-wide moratorium on logging concessions. Although the concession was established as a protected forest soon after, logging tracks increased accessibility into the forest, creating avenues for illegal logging and hunting. In the late 1990s, communities began to invest income from farming into new assets, including motorbikes, housing and village infrastructure, such as pump wells, health posts, and schools.

476 The rehabilitation of Provincial Road 76, linking the provincial town to the capital, coincided with the establishment of economic land concessions, as well as the introduction of cassava by Vietnamese traders and increasing waves of Khmer and Cham migration. These events set the landscape into a rapid and transformative transition, evident by the large scale of deforestation that occurred during this period (Figure I). In all three focus groups, participants described how villagers and new migrants increased their wealth by growing cassava and engaging in the illegal timber market, giving rise to issues of debt, corruption, and elite capture of resources. Key informants emphasised how illegal logging generated wealth for households, but gave various dates for when this activity peaked. According to one farmer in Gati village:

Logging of high value timber began in 2002 when middlemen arrived in village, and peaked in 2006. The villagers benefited, they bought rice, paid labourers to farm their land and upgraded their houses. Now there is less timber, so families have stopped logging and returned to farming. But logging continues to occur because of corruption.

In Chak Char, increased logging coincided with the conversion of neighbouring forest in Snoul Wildlife

491 Sanctuary and part of KSWS to a rubber concession in 2012. Roads built through the rubber concession brought benefits of increased accessibility to the village, but participants in the focus group felt conflict between villagers and the concession and corruption overshadowed these benefits.

495 Similar to the Northern Plains, road rehabilitation in KSWS is followed by new infrastructure, including electricity, cell towers and village buildings, bringing new opportunities to villages. The 2017 REDD+ SIA in

497 KSWS found that in 2012 and 2017, wealthy households were associated with owning more land, operating a 
Remote indigenous communities with strong ties to their environmental surroundings are facing tough decisions

500 on how to ensure their families can access development opportunities while protecting forest for future

501 generations. We spoke with a local representative of the Indigenous Peoples Party, who expressed the

502 challenges of conserving culture in a landscape of changing values and expectations. He felt development had

503 brought positive changes to the village, but was concerned about concessions and migration taking away forest

504 and land from indigenous people.

505

506 Indigenous Communal Tenure (ICT) was recently established in Gati and Chak Char, formalizing indigenous

507 ownership over forest and land. Still in its early stages, key informants in both villages had mixed feelings over

508 the benefits of ICT. They hoped ICT will help to leverage NGO support for conservation and development

509 through the REDD+ project. Yet the perceived value of ICT in delivering social and environmental benefits

510 depended on the functionality of local governing agencies, which varied between villages. As identified in

511 Travers et al. (2015), communal land management is influenced by community leadership, institutions, and

512 shared values within the community, affecting both compliance with local rules and the sustainability of ICT.

513

\section{$514 \quad$ Local perceptions of key events in landscape transitions}

515 In the historical trends analysis, focus groups linked various components of landscape change with individual or

516 household experiences. As such, members identified several events and changes that have had a positive impact

517 on the villages (Figure II). Expanding land-holdings, logging, roads, and cash crop production brought wealth to

518 households, creating development opportunities (Riggs et al., 2020). Participants frequently noted the

519 importance of 'outsiders' or external agents in facilitating these opportunities, particularly the role of middle-

520 men and migrants opening shops and logging. As stated by a young male entrepreneur in KSWS:

521

"It is good that new people arrive, they know outside economics and people can learn from them"

523

524 As shown by Figure II, the villages most accessible by road in each landscape, Sre Preah and Dangphlat,

525 identified more positive changes than the villages with lower road accessibility. Three villages identified

526 logging as positively impacting their development. However, all six villages also identified negative impacts.

527 Logging and the associated corruption negatively affect the environment, which in turn negatively affect

528 people's lives through events such as flooding. In Sre Preah, the focus group viewed the establishment of 
529 microfinance in the village as both positive and negative. Participants noted that microfinance brought

530 opportunities for villagers to increase agricultural production but if yields are low, it can bring debt and

531 difficulty. Currently, both landscapes are undergoing extensive road improvement, and the SIA for REDD+

532 finds that wealth indicators in remote villages of KSWS are catching up to accessible villages (unpublished

533 data).

535 Fig. II Events and changes with the most significant impact on livelihoods and the surrounding environment, as 536 perceived by villagers. Columns show if the event was listed as significant in the focus group discussion that 537 took place in each of the six villages. If the event was identified as a positive impact, it is marked above the 538 black line. Events with a negative impact are marked below the black line. The four events identified with an 539 environmental impact are on the right

540 In focus groups and interviews across all six villages, respondents felt that change positively impacted their 541 communities and life improved with each new generation. At the household level, improvements in livelihoods

542 largely focused on income, reflected in the 2017 household surveys. In response to the question "has your 543 livelihood improved in the past 5 years?", 53\% of households in the Northern Plains and KSWS combined 544 responded "improved" (Figure III). When asked why, 74\% and 60\% of households in Northern Plains and 545 KSWS respectively explicitly referred to income, earnings or involvement in commerce.

547 Fig. III Response to "Has your livelihood improved in the past 5 years" in the 2017 Household Survey in

\section{KSWS and the Northern Plains}

549 During interviews, we also discussed broader aspects of wellbeing linked to sustainable livelihoods, including 550 natural, economic, human and social capitals (Scoones, 1998). Key informants frequently raised subjects of 551 access to land, secure and stable income, healthy family members and fairness when discussing quality of life.

552 Villagers referred to fairness as inclusion in local decision making and development opportunities and fair 553 implementation of local rules. Broader issues regarding corruption and law enforcement that extended beyond 554 social relations in the village were also a concern for many key informants, especially if rules were perceived to 555 unfairly restrict access to land or natural resources. Improvements at the village level or higher were observed to 556 be easier access and better-quality education, infrastructure such as electricity, roads and cell towers, and access 
557 to credit through micro-finance institutions and savings groups. But, as an elderly poor rice farmer observed,

558 village-level improvements had a greater effect on households that could afford to benefit.

"The road has no effect on me because I can't sell rice to the middleman. I do not have a mini-tractor and grow rice only for eating"

Our key informant discussions echoed well-being dimensions explored in-depth in Beauchamp et al (2018), specifically the importance of land. According to some of the poorest households in the villages, land underpins wellbeing. Land is of both instrumental and intrinsic value to Cambodians in rural forest landscapes. Key informants felt that without land, households cannot grow their income, as an elder farmer stated:

Villagers also recognise that land is a scarce resource in both landscapes. According to census information, the populations in Preah Vihear and Mondulkiri provinces are increasing at a rate of over 3\% annually, due to migration and birth rates. Population density is still low in comparison to other provinces, supporting the likelihood that migration rates will stay high in the foreseeable future (Diepart et al., 2014). Many farmers grow fragrant rice which is low yielding, requires fewer inputs but receives a premium price. From the household surveys, average yields for paddy rice are 1.9t/ha in the Northern Plains and 1.6t/ha in KSWS. For cassava, the average yield is 4t/ha in the Northern Plains. In KSWS, cassava productivity has dropped from 3.5t/ha in 2012 to $1.8 \mathrm{t} / \mathrm{ha}$. Declining yield is consistent with reported trends in cassava cultivation across Asia, as continuous cassava production over long periods of time without fertilizer inputs degrades the soil and reduces its productivity (Howeler, 1991). income. In both landscapes, they expected the continued expansion of agriculture to replace forest cover, as well as smaller land parcels, more concessions, and natural hazards due to forest loss. Despite this, participants were woman in the Northern Plains; 
We want [the younger generation] to have a good education and become a teacher or doctor or mechanic

588 because there will not be enough land to farm. We do not want them to move, but to create better jobs in the commune.

590

591 All groups desired improved infrastructure (schools, hospitals, toilets, wells, electricity) and identified a role for government and NGOs in reaching their desired objectives, based on observations of current and past projects.

593 Focus groups in the more remote villages desired improved roads. When we inquired about the future in key

594 informant interviews, responses reflected a focus on the present and less thought for the future, typical of poor

595 rural populations (Banerjee et al., 2011). Interviews echoed the responses in the focus group discussions,

596 expecting forests to decrease but also hoping for the villages to continue to develop. Some interviewees

597 expected their children to farm, others hoped for high skilled jobs through improved education. In KSWS, the 598 representative of the Indigenous Peoples Party spoke of 'protecting poor people in the village from powerful

599 concessions companies that take their land'. His response reflects the pervasive discourse throughout rural

600 Cambodia on dispossession due to land concessions (Baird \& Fox, 2015; Neef et al., 2013).

601

602

Declining forest cover and implications

603 In the 2017 household questionnaires, $98 \%$ of respondents said the forest provided them with benefits. The six

604 most common responses were consistent across both landscapes (Figure IV). In the Northern Plains, 91\% of

605 respondents identified construction as the main benefit from forests. However, in KSWS, respondents were

606 more likely to identify ecosystem services, possibly due to the presence of the REDD+ project.

607

608 Fig. IV Perceived benefits from forests, obtained through household questionnaires in 2017. Participants often

609 identified more than one benefit. Responses were coded into categories. Graph shows frequency of category

610 mentioned in responses

611 Despite recognising indirect values, people tended to be fatalistic about the future of the forest, seeing it as a

612 resource that would eventually diminish for future generations.

613

614 "If we keep clearing land and have no forest then that is our destiny"-Farmer, Northern Plains

615 
616 Focus groups were also not optimistic about the future of the forest. In Gati and Chak Char villages in KSWS,

617 participants wanted help from NGOs to protect the forest for future generations. In interviews we received

618 mixed responses on whether forest should be protected; some felt PAs were inhibiting land expansion and

619 income, others felt the need to conserve forest for future generations. In the Northern Plains, we spoke with

620 villagers involved in bird nest protection who expressed the difficulty of the situation. He said some people were

621 glad to take part in conservation programs, but local authorities also gave permission to villagers to cut trees and

622 clear forest in nesting sites. While they thought stronger law enforcement could strengthen protection, they were

623 uncertain how to bring about that change. No observations were made about change in management for KSWS

624 and CWS from MAFF to MoE. In KSWS, we spoke with an indigenous person who did not see a conflict

625 between conservation and land expansion, but instead emphasised the importance of management.

626

627 "Land clearance is not a problem because indigenous people have managed their lands for generations without

628 harming the forest".

629

630 Our discussions on forests frequently tended to shift towards rights and access, rather than conservation and

631 threats. Views on whether to protect or use the forest were diverse in all villages, but emphasis on the lack of

632 fair rules and implementation remained consistent. During interviews and focus groups, protected forests were

633 at the centre of corruption concerns, including government agencies facilitating illegal logging and inequitable

634 implementation of laws and regulations regarding forest clearance and use. As a result, some of our key

635 informants shared their distrust in village and PA authorities and were concerned about growing disparities

636 between wealthier, well-connected households and poorer households.

637

638 "Only the rich can afford to cut trees. The [conservation intervention] makes poor people poorer and the rich

639 richer".

640

641 Distrust in local authorities was also reported in the KSWS 2017 household survey, with 68\% of households

642 responding no to the question "local leaders consider your concerns when they make decisions that affect you".

643 Similarly, in the Northern Plains 2017 survey, 79\% of households responded disagree to the question "I think

644 that everybody in the village is able to obtain land fairly".

645 


\section{Discussion}

647 Livelihoods in rural Cambodia are improving across generations. Driving this improvement is accessibility,

648 expanding agricultural markets, and resource exploitation. Yet as households have built and accumulated capital

649 in the years following the Khmer Rouge, they have also confronted issues of corruption, elite capture, and

650 inequality. As such, individual perceptions of change and well-being are inseparable from the broader

651 institutional and environmental processes that exist within the landscape. Control of, use of, and access to land

652 has become a key issue of concern in many rural communities, especially those living in and around highly

653 valued tropical forest.

654

655 Development pathways in the Northern Plains and KSWS show similar trends but are unique to the

656 geographical, political and historical circumstances in each place. In KSWS, proximity to the Vietnamese

657 border, earlier accessibility and soil conditions enabled the uptake of cash crops as the dominant livelihood. The

658 social and environmental change resulting from the boom and bust cycle of the cassava crop in Mondulkiri is a

659 primary example (Mahanty \& Milne, 2016). In the Northern Plains, limited accessibility and the longstanding

660 practice of rice cultivation resulted in a slower uptake of cash crops, with mechanized agriculture driving

661 livelihood improvement.

662

663 Currently, villagers in the Northern Plains and KSWS see agricultural expansion as the most viable pathway for

664 improving livelihoods. For some households, migration and an illegal economy of high value timber, is

665 providing the push they need to build assets. Protected areas are constraining expansion, and illegal and corrupt

666 use of forest resources are creating dissatisfaction among villages. Portions of PAs that have not received NGO

667 support and investment are already lost to settlement and are emerging as flourishing rural towns. Remote

668 villages desire better infrastructure and access, and despite recognition of natural values, accept that settlements

669 may replace forests in the future (Riggs et al., 2020). As populations grow, economic activity and migration to

670 these landscapes is likely to continue, intensifying the rate at which forest is converted to other land use. Unlike

671 neighbouring Vietnam, economic growth in Cambodia's forest landscapes is not a yet associated with

672 agricultural intensification (Meyfroidt \& Lambin, 2008a). Forests are still considered an abundant resource and

673 national forest cover is regionally high (FAO, 2015). Observing current trends, it appears unlikely that pressure

674 on forests in Cambodia will decrease in the foreseeable future.

675 
676 We see three plausible scenarios for the future of forest landscapes in Cambodia under different conservation

677 approaches. The three scenarios, described below, draw from the historical trends analysis and aim to capture

678 components of the present that may intensify in the future under different management approaches, such as

679 agricultural expansion, population growth, economic activity, and NGO involvement in the landscape. Different

680 conservation approaches are distinguished to highlight difficult trade-offs in meeting socio-economic and

681 environmental objectives along landscape transitions. By grounding these trade-offs in realistic futures for

682 tropical forest landscapes, we hope to guide decision making for long term engagement in protected areas and

683 rural development. The scenarios are stylized to typify across a spectrum of possibilities and cannot represent

684 the full complexity of the situations they describe. In reality, development pathways will fall along a spectrum

685 due to the complexity and unpredictability of social-ecological systems.

686

687 Under scenario 1, conservation agencies collaboratively prioritise geographic areas for in situ protection of

688 biodiversity at the national or regional level. Prioritization directs resources towards a smaller number of PAs,

689 reducing competition between biodiversity and processes that threaten its existence (Cullen, 2013).

690 Prioritization assumes PAs in Cambodia constrain smallholders and that rural economies will benefit from

691 development opportunities made available through increased land access and security. Several methods are

692 proposed for conservation prioritisation (Margules \& Pressey, 2000; Sarkar et al., 2006), all of which require

693 accurate and comprehensive inventories of components of biodiversity such as taxa sub-sets, habitat types, etc.

694 In this scenario, it is essential that prioritization takes into account social and political conditions that constrain

695 conservation and include tenure, law enforcement, cultural ties to land, and future land use scenarios, in addition

696 to biophysical conditions. Reducing the geographic size of PAs strategically targets resources towards existing

697 conservation, but also allocates resources towards socio-economic programs that can lead to long term

698 conservation wins. For example, secure tenure, infrastructure, and agricultural intensification may reduce

699 smallholder deforestation if supported by good governance (Acheampong et al., 2018; Kubitza et al., 2018;

700 Robinson et al., 2014). This pathway is about getting the human population quickly engaged with potentially

701 prosperous development opportunities and building a constituency for conservation once they are relatively

702 well-off. It assumes that strategic targeting of conservation resources will increase effectiveness, and accepts a

703 degree of loss of biodiversity in exchange for long term conservation outcomes for other species. Broad-scale

704 conservation is a future by-product of development in this pathway. 
706 In scenario 2, existing PAs are retained, and conservation agencies restrict development to protect ecological

707 integrity. The entire area of intact forest inside PAs is considered core conservation and cannot be allocated for

708 future conversion. Smallholders are considered a threat to PAs, and conservation agencies take strict actions to

709 prevent encroachment and logging. Proposed infrastructure development is subject to rigorous environmental

710 impact assessment, and remote communities remain inaccessible to avert negative repercussions of road

711 development. Conservation agencies attempt to restrict the use of chemicals in agriculture and all wildlife

712 hunting is banned. As a result, rural economies remain socio-economically stagnant; they are not able to

713 intensify their agriculture, and they are penalized for logging or expanding agricultural land. In this future

714 scenario, conservation agencies direct their resources towards threat-based conservation, responding to stresses

715 instead of into long-term strategic planning, or proactive, adaptive theories of change. Conservation programs

716 such as birds nest protection and wildlife friendly rice do not exist, and farmers struggle to increase their

717 income. Day-to-day conservation activities in this scenario might correspond to what Boedhihartono et al.

718 (2018) describes as whack-a-mole, in which interventions are triggered by issue-cycles and populism, instead of

719 an integrated long-term approach to solving problems within a system. Threat-based measures taken by

720 conservation organizations create animosity among local farmers and drive insidious exploitation, resulting in a

721 degraded and unproductive landscape, and death by a thousand cuts (Laurance, 2010). Strict protection may lead

722 to social conflict and immigration out of PAs. A key assumption in this scenario is the power of conservation

723 agencies to carry out strict protection and have the highest authority on land use decisions. Recent conversion of

724 large tracts of PAs in Cambodia to industrial agriculture (Yin, 2017) suggest conservation agencies may not be

725 able to withstand forest conversion by powerful elites, reinforcing the notion that it will be poor smallholders

726 who suffer under this scenario.

727

728 Scenario 3 can be characterised as incremental change, as it describes a landscape that is transitioning gradually.

729 In this scenario, Cambodia continues to designate significant land to protection, but all PAs are zoned as

730 required by the 2008 Protected Area Law. Strict conservation areas exist in a mosaic of core, conservation,

731 sustainable use, and community zones. The sustainable use zone is used for ecotourism, community forestry,

732 recreation, mining, and economic land concessions. Incremental change assumes a degree of muddling through

733 (Lindblom, 1959), in which decisions are made in response to social, economic and political signals, with the

734 best available but incomplete information at the time. Indigenous Communal Tenure exists in the mosaic of land

735 uses, and remote communities are gradually more accessible as they become recipients of infrastructure 
736 initiatives led by government and non-government agencies. Endangered species remain at high risk due to

737 smallholder forest conversion as accessibility within PAs increases, but over time households depend more on

738 off-farm income to improve wellbeing. In this scenario, agencies use community-based conservation approaches

739 to support local livelihoods and meet conservation goals. Conservation initiatives compete with more lucrative

740 livelihood opportunities, limiting their ability to reduce degradation and deforestation (Brooks et al., 2013;

741 Wright et al., 2016). As rural communities accumulate wealth over generations, forests are degraded and

742 gradually decline. Incremental change assumes that zoning PAs will reduce pressures on forests, as communities

743 are not strictly excluded. Yet the opportunity cost is high for locals to conserve their lands. Despite the presence

744 of community conservation programs, locals pursue livelihoods that make the most sense to them and their

745 economic needs. As a consequence, rural households continue to seek livelihoods that compete with

746 conservation, and conservation agencies must continue to respond to changing conditions.

\section{Collaborative governance of landscape transitions}

749 Governance arrangements in each scenario described above will evolve differently, both affected by and

750 affecting conservation and development outcomes. Good governance, including secure property rights,

751 democratic participation, accountability, trust in collective leadership, and a conducive policy environment,

752 would underpin prosperous and environmentally sustainable rural landscapes in Cambodia.

753

754 If the conservation strategy is to support a gradual shift to a sustainably managed mosaic landscape,

755 conservation agencies would add value by contributing to a conducive institutional setting that supports

756 collaborative approaches for governing systems (Armitage et al., 2012; Lockwood et al., 2010). The recent

757 decentralization of natural resource management to the provincial level in Cambodia creates a window of

758 opportunity for collaborative governance of PAs. Decentralized systems offer potential advantages such as

759 subsidiarity, shared decision making authority, and democratic involvement in the allocation of resources

760 (Colfer \& Capistrano, 2005). Yet they also raise significant risks, such as elite capture and resource exploitation,

761 especially if inhibited by governance constraints (Tacconi, 2007). The actors that can influence the social and

762 environmental outcomes of landscape transitions are not restricted to conservation agencies; they include the

763 informal and formal leaders within the village and at higher levels. Robust relationships characterized by high

764 levels of communication and clear perceptions of roles and responsibilities among these leaders is fundamental

765 for consensus driven decision making and navigating trade-offs. If conservation agencies can work with key 
766 local decision makers, they can strengthen their capacity for good governance, which may lead to mutually

767 beneficial collective action with positive social and environmental outcomes (Beauchamp et al., 2019).

769 Recognising the difficulties of collaborative governance of natural resource management systems, it may be that 770 conservation agencies are limited in their ability to refocus existing operations with the goal of improving

771 governance. The experiences of conservation bodies in the Northern Plains and KSWS demonstrate the value of

772 long-term engagement, and the continued challenges that arise. In both cases, multiple methods and disciplines

773 have contributed to a better understanding of the social and political attributes that influence conservation and

774 development outcomes and have led to evidence based interventions (Clements, 2012; Evans, 2013). While

775 other PAs in Cambodia are also co-managed by NGOs, many do not receive the same support, and are faced

776 with similar or more extreme challenges. In the Northern Plains and KSWS, WCS works directly with local

777 decision makers to strengthen their capability for natural resource management. Yet, as the pace and nature of

778 landscape transitions evolve, conservation strategies must be continually revisited and adapted to local

779 conditions (Langston et al., 2019). Building rich histories and understanding local perceptions of change can

780 ensure that interventions to improve livelihoods connect with major economic opportunities. Approaches that

781 strengthen governance and foster collaboration can help achieve targeted and contextually driven conservation

782 and development objectives (Bennett et al., 2019)

783

784 We observed two initiatives that offer an opportunity for strengthening partnerships for better governance and

785 leveraging change for sustainability. In the Eastern Plains, conservation organizations are working with

786 indigenous groups to formalize Indigenous Communal Tenure, providing secure access and ownership over land

787 to indigenous communities. These partnerships also provide mechanisms for distributing and managing funding

788 for the REDD+ project in KSWS. Some villagers we spoke with were enthusiastic about community driven

789 schemes for protecting forests, but clearly stated needs for building capacity, authority and financial resources.

790 In the Northern Plains, three conservation projects, a bird nest protection program, a premium payment scheme

791 for wildlife-friendly rice, and an ecotourism program are providing incentives for communities to engage in

792 conservation, with economic benefits (Beauchamp et al., 2018a). These projects are strengthening collaboration

793 between conservation agencies and local government agencies, creating a space for regular interaction and

794 dialogue that could mobilize and engage more actors. 


\section{Conclusion}

797 Tropical forest landscapes in Southeast Asia are in transition. While some countries experience net gains in

798 forest cover, others are experiencing net loss with no indication of reaching a turning point (Austin et al., 2019;

799 Riggs et al., 2018). The situation at sub-national levels is highly dynamic and diverse, with many forest

800 landscapes confronting similar realities of the conservation development nexus (Langston et al., 2017; Mahanty

801 \& Milne, 2015; Sodhi et al., 2010). Long-term trends indicate that economic development may resolve short-

802 term environmental concerns, but only if there is a supportive institutional and macro-economic environment

803 (Liu et al., 2016). Understanding, interpreting and navigating immediate pressures for social, political,

804 economic, and environmental demands of managing forest landscapes is inherently difficult. Situations are often

805 highly complex and beyond the direct control of decision makers (Evans et al., 2017). Yet, if conservation

806 scientists wish to embed themselves in tropical forest landscapes to protect biodiversity and environmental

807 services, they must be prepared to reconcile conservation and development trade-offs (Langston et al., 2019).

808

809 Our results demonstrate the difficult trade-offs required if conservation is to better serve the needs of people

810 living in tropical forest landscapes. In Cambodia, win-win scenarios meeting both biodiversity conservation and

811 short term development goals do not exist. Conservation agencies will have to work with decision makers at

812 multiple scales to strengthen governance and explore realistic scenarios for the future of protected areas and

813 rural development. Harbouring realistic expectations, understanding that trade-offs are necessary and making

814 those trade-offs explicit can help conservation agencies target their efforts to protect biodiversity accurately

815 whilst contributing to the development of prosperous rural communities. 
Acheampong, E. O., Sayer, J., \& Macgregor, C. J. (2018). Road improvement enhances smallholder productivity and reduces forest encroachment in Ghana. Environmental Science \& Policy, 85, 64-71.

ADB. (2012). Greater Mekong Subregion Economic Cooperation Program Overview. In. the Philippines: Asian Development Bank.

ADB. (2016). Asian Development Outlook 2016: Asia's potential growth. Retrieved from Manila, Philippines: https://www.adb.org/sites/default/files/publication/182221/ado2016.pdf

Adger, W. N., Brown, K., Fairbrass, J., Jordan, A., Paavola, J., Rosendo, S., \& Seyfang, G. (2003). Governance for Sustainability: Towards a 'Thick' Analysis of Environmental Decisionmaking. Environment and Planning A: Economy and Space, 35(6), 1095-1110. doi:10.1068/a35289

Agrawal, A., \& Gibson, C. C. (2001). Communities and the environment: ethnicity, gender, and the state in community-based conservation: Rutgers University Press.

Altman, I., \& Low, S. M. (2012). Place attachment (Vol. 12): Springer Science \& Business Media.

Armitage, D., de Loë, R., \& Plummer, R. (2012). Environmental governance and its implications for conservation practice. Conservation Letters, 5(4), 245-255.

Austin, K. G., Schwantes, A., Gu, Y., \& Kasibhatla, P. S. (2019). What causes deforestation in Indonesia? Environmental Research Letters, 14(2), 024007.

Bailes, K. E. (1985). Environmental History: Critical Issues in Comparative Perspective: University Press of America.

Baird, I., \& Fox, J. (2015). How land concessions affect places elsewhere: Telecoupling, political ecology, and large-scale plantations in southern Laos and northeastern Cambodia. Land, 4(2), 436-453.

Balmford, A., \& Cowling, R. M. (2006). Fusion or failure? The future of conservation biology. Conservation Biology, 20(3), 692-695.

Banerjee, A. V., Banerjee, A., \& Duflo, E. (2011). Poor economics: A radical rethinking of the way to fight global poverty: Public Affairs.

Barlow, J., Lennox, G. D., Ferreira, J., Berenguer, E., Lees, A. C., Mac Nally, R., . . Oliveira, V. H. F. (2016). Anthropogenic disturbance in tropical forests can double biodiversity loss from deforestation. Nature, 535(7610), 144.

Basuki, I., Sheil, D., Padmanaba, M., Liswanti, N., Mulcahy, G., \& Wan, M. (2011). The evolving role of tropical forests for local livelihoods in Indonesia. International Journal of Environment and Sustainable Development, 10(3), 267-287.

Beauchamp, E., Clements, T., \& Milner-Gulland, E. (2018a). Assessing Medium-term Impacts of Conservation Interventions on Local Livelihoods in Northern Cambodia. World development, 101, 202-218.

Beauchamp, E., Clements, T., \& Milner-Gulland, E. (2018b). Exploring trade-offs between development and conservation outcomes in Northern Cambodia. Land Use Policy, 71, 431-444.

Beauchamp, E., Clements, T., \& Milner-Gulland, E. (2019). Investigating Perceptions of Land Issues in a Threatened Landscape in Northern Cambodia. Sustainability, $11(21), 5881$.

Beban, A., So, S., \& Un, K. (2017). From Force to Legitimation: Rethinking Land Grabs in Cambodia. Development and change.

Bennett, N. J., Di Franco, A., Calò, A., Nethery, E., Niccolini, F., Milazzo, M., \& Guidetti, P. (2019). Local support for conservation is associated with perceptions of good governance, social impacts, and ecological effectiveness. Conservation Letters, $0(0)$, e12640. doi:10.1111/conl.12640

Berkes, F., Colding, J., \& Folke, C. (2008). Navigating social-ecological systems: building resilience for complexity and change: Cambridge University Press.

Berkes, F., \& Folke, C. (1998). Linking social and ecological systems for resilience and sustainability: management practices and social mechanisms for building resilience. Cambridge, UK: Cambridge University Press, .

Boedhihartono, A. K. (2012). Visualizing sustainable landscapes : understanding and negotiating conservation and development trade-offs using visual techniques. Gland, Switzerland: Iucn.

Boedhihartono, A. K., Bongers, F., Boot, R. G., van Dijk, J., Jeans, H., van Kuijk, M., . . Sunderland, T. (2018). Conservation Science and Practice Must Engage With the Realities of Complex Tropical Landscapes. Tropical Conservation Science, 11, 1940082918779571.

Brandt, P., Ernst, A., Gralla, F., Luederitz, C., Lang, D. J., Newig, J., . . Von Wehrden, H. (2013). A review of transdisciplinary research in sustainability science. Ecological Economics, 92, 1-15.

Brooks, J., Waylen, K. A., \& Mulder, M. B. (2013). Assessing community-based conservation projects: a systematic review and multilevel analysis of attitudinal, behavioral, ecological, and economic outcomes. Environmental Evidence, 2(1), 2. 
Brown, K. (2002). Innovations for conservation and development. Geographical Journal, 168(1), 6-17.

Brown, K. (2004). Trade-off analysis for integrated conservation and development. McShane, TO and Wells, $M P, 232-255$.

Brown, V., Gutknecht, J., Harden, L., Harrison, C., Hively, D., Jørgensen, C., . . Wang, Y. (2010). Understanding and engaging values in policy relevant science. Bulletin of the British Ecological Society, 41, 48-56.

Bürgi, M., Hersperger, A. M., \& Schneeberger, N. (2005). Driving forces of landscape change-current and new directions. Landscape Ecology, 19(8), 857-868.

Cheng, A. S., Kruger, L. E., \& Daniels, S. E. (2003). " Place" as an integrating concept in natural resource politics: Propositions for a social science research Agenda. Society \&Natural Resources, 16(2), 87-104.

Clements, G. R., Lynam, A. J., Gaveau, D., Yap, W. L., Lhota, S., Goosem, M., . . Laurance, W. F. (2014a). Where and how are roads endangering mammals in Southeast Asia's forests? PloS one, 9(12), e115376.

Clements, T. (2012). Money for Something? Investigating the effectiveness of biodiversity conservation interventions in the Northern Plains of Cambodia. PhD Thesis, University of Cambridge, Cambridge, 232 pages.

Clements, T., \& Milner-Gulland, E. (2015). Impact of payments for environmental services and protected areas on local livelihoods and forest conservation in northern Cambodia. Conservation Biology, 29(1), 78-87.

Clements, T., Rainey, H., An, D., Rours, V., Tan, S., Thong, S., . . Milner-Gulland, E. (2013). An evaluation of the effectiveness of a direct payment for biodiversity conservation: the bird nest protection program in the Northern Plains of Cambodia. Biological conservation, 157, 50-59.

Clements, T., Suon, S., Wilkie, D. S., \& Milner-Gulland, E. J. (2014b). Impacts of Protected Areas on Local Livelihoods in Cambodia. World development, 64, Supplement 1, S125-S134. doi:http://dx.doi.org/10.1016/j.worlddev.2014.03.008

Cock, A. (2016). Governing Cambodia's Forests. Copenhagen, Denmark: NIAS Press.

Colfer, C. J. P., \& Capistrano, D. (2005). The politics of decentralization: forests, people and power: Earthscan.

Corbin, J. M., \& Strauss, A. (1990). Grounded theory research: Procedures, canons, and evaluative criteria. Qualitative sociology, 13(1), 3-21.

Cornell, S., Berkhout, F., Tuinstra, W., Tàbara, J. D., Jäger, J., Chabay, I., . . Moll, P. (2013). Opening up knowledge systems for better responses to global environmental change. Environmental Science \& Policy, 28, 60-70.

Cullen, R. (2013). Biodiversity protection prioritisation: a 25-year review. Wildlife Research, 40(2), 108-116.

Curran, L. M., Trigg, S. N., McDonald, A. K., Astiani, D., Hardiono, Y., Siregar, P., . . Kasischke, E. (2004). Lowland forest loss in protected areas of Indonesian Borneo. Science, 303(5660), 1000-1003.

Davies, R., \& Smith, W. (1998). The Basic necessities survey: the experience of action aid Vietnam. London: Action Aid.

Davis, K. F., Yu, K., Rulli, M. C., Pichdara, L., \& D’Odorico, P. (2015). Accelerated deforestation driven by large-scale land acquisitions in Cambodia. Nature Geoscience, 8(10), 772-775.

Dewi, S., Van Noordwijk, M., Zulkarnain, M. T., Dwiputra, A., Hyman, G., Prabhu, R., . . Nasi, R. (2017). Tropical forest-transition landscapes: a portfolio for studying people, tree crops and agro-ecological change in context. International Journal of Biodiversity Science, Ecosystem Services \& Management, 13(1), 312-329.

Diepart, J.-C., Pilgrim, J., \& Dulioust, J. (2014). Migrations. Atlas of Cambodia: Maps on Socio-Economic Development and Environment, 89-96.

Estoque, R. C., Ooba, M., Avitabile, V., Hijioka, Y., DasGupta, R., Togawa, T., \& Murayama, Y. (2019). The future of Southeast Asia's forests. Nature Communications, 10(1), 1829. doi:10.1038/s41467-01909646-4

Evans, M. C., Davila, F., Toomey, A., \& Wyborn, C. (2017). Embrace complexity to improve conservation decision making. Nature ecology \& evolution, 1(11), 1588.

Evans, T. (2013). "Seima Protection Forest, Cambodia.” Chapter 12 in Evidence-based conservation: lessons from the lower Mekong. In: Rutledge.

Evans, T., Bauran, H., \& Delattre, E. (2009). Deforestation rates in and around the Seima Biodiversity Conservation Area, Cambodia, 2001-2007. Wildlife Conservation Society, Phnom Penh, Cambodia.

FAO. (2015). Global Forest Resources Assessment 2015: Desk reference. UN Food and Agriculture Organisation, Rome.

FAO. (2016). State of the World's Forests 2016. Forests and agriculture: land-use challenges and opportunities. Rome.

Fischer, J., Meacham, M., \& Queiroz, C. (2017). A plea for multifunctional landscapes. Frontiers in Ecology and the Environment, 15(2), 59-59.

Ghazoul, J., \& Chazdon, R. (2017). Degradation and recovery in changing forest landscapes: a multiscale conceptual framework. Annual review of environment and resources, 42, 161-188. 

governance: Mit Press.

Graham, J., Amos, B., \& Plumptre, T. W. (2003). Governance principles for protected areas in the 21st century: Institute on Governance, Governance Principles for Protected Areas.

Gray, T. N., \& Phan, C. (2011). Habitat preferences and activity patterns of the larger mammal community in Phnom Prich Wildlife Sanctuary, Cambodia. The Raffles Bulletin of Zoology, 59(2), 311-318.

Greider, T., \& Garkovich, L. (1994). Landscapes: The social construction of nature and the environment. Rural sociology, 59(1), 1-24.

Hansen, M. C., Potapov, P. V., Moore, R., Hancher, M., Turubanova, S., Tyukavina, A., . . Loveland, T. (2013). High-resolution global maps of 21st-century forest cover change. Science, 342(6160), 850-853.

Harrison, S., \& Mao, K. (2017). An update to the birds nest protection programme in the Northern Plains of Cambodia, 2009-2016. Wildlife Conservation Society, Cambodia Programme, Phnom Penh.

Hirsch, P. D., Adams, W. M., Brosius, J. P., Zia, A., Bariola, N., \& Dammert, J. L. (2011). Acknowledging conservation trade-offs and embracing complexity. Conservation Biology, 25(2), 259-264.

Howeler, R. (1991). Long-term effect of cassava cultivation on soil productivity. Field crops research, 26(1), 118.

Hughes, C., \& Un, K. (2011). Cambodia's economic transformation: Nias Press.

Ibbett, H., Lay, C., Phlai, P., Song, D., Hong, C., Mahood, S. P., \& Milner-Gulland, E. (2017). Conserving a globally threatened species in a semi-natural, agrarian landscape. Oryx, $1-11$.

Ichikawa, K., Okubo, N., Okubo, S., \& Takeuchi, K. (2006). Transition of the satoyama landscape in the urban fringe of the Tokyo metropolitan area from 1880 to 2001. Landscape and Urban Planning, 78(4), 398410.

Jiao, X., Pouliot, M., \& Walelign, S. Z. (2017). Livelihood strategies and dynamics in rural Cambodia. World development, 97, 266-278.

Johnson, E., Hyde, R., \& Rosenfeld, T. (2014). Corruption and Cambodia's Governance System The Need for Reform. Transparancy International Cambodia, Phnom Penh, Kingdom of Cambodia.

Kaplan, D. M., \& White, C. G. (2002). Integrating landscape ecology into natural resource management: Cambridge University Press.

Kong, R., Diepart, J.-C., Castella, J.-C., Lestrelin, G., Tivet, F., Belmain, E., \& Bégué, A. (2019). Understanding the drivers of deforestation and agricultural transformations in the Northwestern uplands of Cambodia. Applied geography, 102, 84-98. doi:https://doi.org/10.1016/j.apgeog.2018.12.006

Kremen, C. (2015). Reframing the land-sparing/land-sharing debate for biodiversity conservation. Annals of the New York Academy of Sciences, 1355(1), 52-76.

Kubitza, C., Krishna, V. V., Urban, K., Alamsyah, Z., \& Qaim, M. (2018). Land Property Rights, Agricultural Intensification, and Deforestation in Indonesia. Ecological Economics, 147, 312-321. doi:https://doi.org/10.1016/j.ecolecon.2018.01.021

Lambin, E. F., \& Meyfroidt, P. (2010). Land use transitions: Socio-ecological feedback versus socio-economic change. Land Use Policy, 27(2), 108-118.

Lang, D. J., Wiek, A., Bergmann, M., Stauffacher, M., Martens, P., Moll, P., ... Thomas, C. J. (2012). Transdisciplinary research in sustainability science: practice, principles, and challenges. Sustainability Science, 7(1), 25-43.

Langston, J., Riggs, R., Sururi, Y., Sunderland, T., \& Munawir, M. (2017). Estate Crops More Attractive than Community Forests in West Kalimantan, Indonesia. Land, 6(1), 12. doi:10.3390/land6010012

Langston, J. D., Riggs, R. A., Sayer, J. A., Margules, C., \& Boedhihartono, A. K. (2019). Science embedded in local forest landscape management improves benefit flows to society. Frontiers in Forests and Global Change, 2,3 .

Laurance, W. F. (2007). Have we overstated the tropical biodiversity crisis? Trends in ecology \& evolution, $22(2), 65-70$.

Laurance, W. F. (2010). Habitat destruction: death by a thousand cuts. Conservation biology for all, 1(9), 73-88.

Laurance, W. F., \& Arrea, I. B. (2017). Roads to riches or ruin? Science, 358(6362), 442-444.

Le Billon, P. (2000). The political ecology of transition in Cambodia 1989-1999: war, peace and forest exploitation. Development and change, 31(4), 785-805.

Leavy, P. (2016). Essentials of transdisciplinary research: Using problem-centered methodologies: Routledge.

Leblond, J.-P. (2019). Revisiting forest transition explanations: The role of "push" factors and adaptation strategies in forest expansion in northern Phetchabun, Thailand. Land Use Policy, 83, 195-214.

Lewis, S. L., Edwards, D. P., \& Galbraith, D. (2015). Increasing human dominance of tropical forests. Science, $349(6250), 827-832$.

LICADHO. (2015). On Stony Ground: A look into social land concessions. Retrieved from http://www.licadhocambodia.org/reports/files/208LICADHOReport-LASEDSocialLandConcessions2015-English.pdf 
994

995

996

997

998

999

1000

1001

1002

1003

1004

1005

1006

1007

1008

1009

1010

1011

1012

1013

1014

1015

1016

1017

1018

1019

1020

1021

1022

1023

1024

1025

1026

1027

1028

1029

1030

1031

1032

1033

1034

1035

1036

1037

1038

1039

1040

1041

1042

1043

1044

1045

1046

1047

1048

1049

1050

1051

Lindblom, C. E. (1959). The science of" muddling through". Public administration review, 79-88.

Liu, J., Liang, M., Li, L., Long, H., \& De Jong, W. (2016). Comparative study of the forest transition pathways of nine Asia-Pacific countries. Forest Policy and Economics.

Lockwood, M., Davidson, J., Curtis, A., Stratford, E., \& Griffith, R. (2010). Governance principles for natural resource management. Society and Natural Resources, 23(10), 986-1001.

Mahanty, S., \& Milne, S. (2015). Conservation and Development in Cambodia : Exploring Frontiers of Change in Nature, State and Society. Abingdon, Oxon: Routledge.

Mahanty, S., \& Milne, S. (2016). Anatomy of a boom: Cassava as a 'gateway'crop in Cambodia's north eastern borderland. Asia Pacific Viewpoint, 57(2), 180-193.

Margules, C. R., \& Pressey, R. L. (2000). Systematic conservation planning. Nature, 405(6783), 243.

Mather, A. (1992). The forest transition. Area, 367-379.

McShane, T. O., Hirsch, P. D., Trung, T. C., Songorwa, A. N., Kinzig, A., Monteferri, B., ... O’Connor, S. (2011). Hard choices: Making trade-offs between biodiversity conservation and human well-being. Biological conservation, 144(3), 966-972. doi:http://dx.doi.org/10.1016/j.biocon.2010.04.038

Meadows, D. H. (1999). Leverage points: Places to intervene in a system. Retrieved from http://www.scrummaster.dk/lib/AgileLeanLibrary/People/DonellaMeadows/donellameadows.orgLeverage \%20Points\%20Places\%20to\%20Intervene\%20in\%20a\%20System.pdf

Mehrabi, Z., Ellis, E. C., \& Ramankutty, N. (2018). The challenge of feeding the world while conserving half the planet. Nature Sustainability, 1(8), 409-412. doi:10.1038/s41893-018-0119-8

Meyfroidt, P., Chowdhury, R. R., de Bremond, A., Ellis, E. C., Erb, K.-H., Filatova, T., . . Kuemmerle, T. (2018). Middle-range theories of land system change. Global Environmental Change, 53, 52-67.

Meyfroidt, P., \& Lambin, E. F. (2008a). The causes of the reforestation in Vietnam. Land Use Policy, 25(2), 182-197.

Meyfroidt, P., \& Lambin, E. F. (2008b). Forest transition in Vietnam and its environmental impacts. Global Change Biology, 14(6), 1319-1336.

Miller, J. R., \& Hobbs, R. J. (2002). Conservation where people live and work. Conservation Biology, 16(2), 330-337.

Milne, S. (2015). Cambodia's Unofficial Regime of Extraction: Illicit Logging in the Shadow of Transnational Governance and Investment. Critical Asian Studies, 47(2), 200-228.

Mittermeier, R. A. (2004). Hotspots revisited: Cemex.

Morales-Hidalgo, D., Oswalt, S. N., \& Somanathan, E. (2015). Status and trends in global primary forest, protected areas, and areas designated for conservation of biodiversity from the Global Forest Resources Assessment 2015. Forest Ecology and Management, 352, 68-77.

Neef, A., Touch, S., \& Chiengthong, J. (2013). The politics and ethics of land concessions in rural Cambodia. Journal of Agricultural and Environmental Ethics, 26(6), 1085-1103.

Newing, H. (2010). Conducting research in conservation: social science methods and practice: Routledge.

NIIS. (2019). General Population Census of the Kingdom of Cambodia 2019. National Institute of Statistics, Ministry of Planning. Retrieved from http://www.nis.gov.kh/nis/Census2019/Provisional\%20Population\%20Census\%202019 English FIN AL.pdf

Ostrom, E. (2009). A General Framework for Analyzing Sustainability of Social-Ecological Systems. Science, 325(5939), 419-422. doi:10.1126/science.1172133

Paley, R. (2015). Managing protected areas in Cambodia: The challenge for conservation bureacracies in a hostile governance environment. In S. Mahanty \& S. Milne (Eds.), Conservation and Development in Cambodia: Exploring Frontiers of Change in Nature, State and Society. Abingdon, Oxon: Routledge.

Palomo, I., Montes, C., Martín-López, B., González, J. A., García-Llorente, M., Alcorlo, P., \& Mora, M. R. G. (2014). Incorporating the Social-Ecological Approach in Protected Areas in the Anthropocene. BioScience, 64(3), 181-191. doi:10.1093/biosci/bit033

Persson, J., \& Prowse, M. (2017). Collective action on forest governance: An institutional analysis of the Cambodian community forest system. Forest Policy and Economics, 83, 70-79.

Phalan, B., Onial, M., Balmford, A., \& Green, R. E. (2011). Reconciling food production and biodiversity conservation: land sharing and land sparing compared. Science, 333(6047), 1289-1291.

Pokorny, B., \& De Jong, W. (2015). Smallholders and forest landscape transitions: Locally devised development strategies of the tropical Americas. International Forestry Review, 17(S1), 1-19.

Rainey, H., Bauran, H., \& Evans, T. (2010). Forest Cover Trends in the Northern Plains of Cambodia 20022010. Wildlife Conservation Society, Phnom Penh, Cambodia.

Redford, K. H. (1992). The empty forest. BioScience, 42(6), 412-422.

Reed, J. (2006). Appreciative inquiry: Research for change: Sage. 
Riggs, R. A., Langston, J. D., \& Sayer, J. (2018). Incorporating governance into forest transition frameworks to understand and influence Cambodia's forest landscapes. Forest Policy and Economics, 96, 19-27. doi:https://doi.org/10.1016/j.forpol.2018.08.003

Riggs, R. A., Langston, J. D., Sayer, J., Sloan, S., \& Laurance, W. F. (2020). Learning from Local Perceptions for Strategic Road Development in Cambodia's Protected Forests. Tropical Conservation Science, 13, 1940082920903183. doi:10.1177/1940082920903183

Roberts, P., Kc, S., \& Rastogi, C. (2006). Rural access index: a key development indicator. World Bank, Washington D.C.

Robinson, B. E., Holland, M. B., \& Naughton-Treves, L. (2014). Does secure land tenure save forests? A metaanalysis of the relationship between land tenure and tropical deforestation. Global Environmental Change, 29, 281-293. doi:10.1016/j.gloenvcha.2013.05.012

Rose, D. C. (2015). The case for policy-relevant conservation science. Conservation Biology, 29(3), 748-754.

Russell, E. W. B. (1998). People and the land through time: linking ecology and history: Yale University Press.

Sarkar, S., Pressey, R. L., Faith, D. P., Margules, C. R., Fuller, T., Stoms, D. M., ... Williams, P. H. (2006). Biodiversity conservation planning tools: present status and challenges for the future. Annual Review of Environment and Resources, 31.

Scholz, R. W. (2000). Mutual learning as a basic principle of transdisciplinarity. Transdisciplinarity: Joint problem-solving among science, technology and society. Workbook II: Mutual learning sessions, 1317.

Scoones, I. (1998). Sustainable rural livelihoods: a framework for analysis.

Shepherd, G., \& Blockhus, J. (2008). PROFOR Poverty-Forests Linkages Toolkit. Retrieved January, 6, 2011.

Sodhi, N. S., Koh, L. P., Clements, R., Wanger, T. C., Hill, J. K., Hamer, K. C., . . Lee, T. M. (2010). Conserving Southeast Asian forest biodiversity in human-modified landscapes. Biological conservation, 143(10), 2375-2384.

Souter, N., J, Simpson, V., Mould, A., Eames, J. C., Gray, T. N., Sinclair, R., . . Billingsley, A. (2016). Will the recent changes in protected area management and the creation of five new protected areas improve biodiversity conservation in Cambodia? Cambodian Journal of Natural History, 1.

Szirmai, A. (2012). Industrialisation as an engine of growth in developing countries, 1950-2005. Structural change and economic dynamics, 23(4), 406-420.

Tacconi, L. (2007). Decentralization, forests and livelihoods: Theory and narrative. Global Environmental Change, 17(3), 338-348. doi:https://doi.org/10.1016/j.gloenvcha.2007.01.002

Terborgh, J., \& Peres, C. A. (2017). Do Community-Managed Forests Work? A Biodiversity Perspective. Land, $6(2), 22$.

Thaler, R. H., \& Sunstein, C. R. (2009). Nudge: Improving decisions about health, wealth, and happiness: Penguin.

Thomas, D. R. (2006). A general inductive approach for analyzing qualitative evaluation data. American journal of evaluation, 27(2), 237-246.

Travers, H., Clements, T., \& Milner-Gulland, E. (2016). Predicting responses to conservation interventions through scenarios: A Cambodian case study. Biological conservation, 204, 403-410.

Travers, H., Winney, K., Clements, T., Evans, T., \& Milner-Gulland, E. (2015). A tale of two villages: An investigation of conservation-driven land tenure reform in a Cambodian Protection Forest. Land Use Policy, 43, 186-196.

Tullock, G. (1967). Theory of rent seeking. Western Economic Journal, 5(3), 224-223.

Turnheim, B., Berkhout, F., Geels, F., Hof, A., McMeekin, A., Nykvist, B., \& van Vuuren, D. (2015). Evaluating sustainability transitions pathways: Bridging analytical approaches to address governance challenges. Global Environmental Change, 35, 239-253.

van Noordwijk, M. (2017). Integrated natural resource management as pathway to poverty reduction: Innovating practices, institutions and policies. Agricultural systems.

Walters, B. B. (2017). Explaining rural land use change and reforestation: A causal-historical approach. Land Use Policy, 67, 608-624.

Warrener, D. (2004). The Drivers of Change Approach. Overseas Development Institute. Retrieved from https://www.odi.org/sites/odi.org.uk/files/odi-assets/publications-opinion-files/3721.pdf

Williams, D. R., \& Stewart, S. I. (1998). Sense of place: An elusive concept that is finding a home in ecosystem management. Journal of forestry, 96(5), 18-23.

Wood, R., \& Handley, J. (2001). Landscape dynamics and the management of change. Landscape research, 26(1), 45-54.

Wright, J. H., Hill, N. A., Roe, D., Rowcliffe, J. M., Kümpel, N. F., Day, M., . . Milner-Gulland, E. (2016). Reframing the concept of alternative livelihoods. Conservation Biology, 30(1), 7-13.

Wright, S. J. (2003). The myriad consequences of hunting for vertebrates and plants in tropical forests. Perspectives in Plant Ecology, evolution and systematics, 6(1-2), 73-86. 
1112 Yin, D. (2017). Systematic \& rapid assessment of concessions using GIS \& remote sensing: The case of economic land concessions in Cambodia. Paper presented at the World Bank Land \& Poverty Conference, Washington DC.

Zhang, Y., Wang, T., Cai, C., Li, C., Liu, Y., Bao, Y., \& Guan, W. (2016). Landscape pattern and transition under natural and anthropogenic disturbance in an arid region of northwestern China. International Journal of Applied Earth Observation and Geoinformation, 44, 1-10. doi:https://doi.org/10.1016/j.jag.2015.06.013 